\title{
Rede empresarial: a estratégia da produção de sementes de soja transgênica em Goiás
}

Business networking: the strategy of soy seeds transgenic production in Goiás Réseau d'entreprise: la stratégie de production de semences de soja transgéniques en Goiás

Red empresarial: la estrategia de la producción de semillas de soja transgénica en Goiás

\author{
Luís Cláudio Martins de Moura* \\ Joel Bevilaqua Marin**
}

Recebido em 28/12/2011; revisado e aprovado em 15/03/2012; aceito em 02/04/2012

\begin{abstract}
Resumo: O objetivo deste artigo é analisar a rede empresarial de produção de semente de soja transgênica no estado de Goiás. A principal rede de produção de semente de soja transgênica adaptada ao cerrado é constituída pela parceria entre Monsanto, Embrapa e Centro Tecnológico para Pesquisas Agropecuárias. Conclui-se que a Monsanto ocupa uma posição hegemônica na rede empresarial.

Palavras-chave: Rede de empresas. Reestruturação produtiva. Estratégias empresariais.

Abstract: the aim of this study is to analyze the business networking transgenic soybean seed production in the state of Goias. The main seed production of transgenic soybean Cerrado is constituted by Monsanto, Embrapa and CTPA. It's concluded that Monsanto holds a hegemonic position in this partnership.

Keywords: Business networking. Productive restructuring. Business strategies.

Résumé: L'objectif de cet article est d'analyser la réseau d'entreprise pour la production de semences du soja transgénique dans l'état de Goias - Brésil. La principal réseau de production de semences de soja transgénique adaptées au Cerrado brésilien est constituée par Monsanto, l'Embrapa et le Centro Tecnológico para Pesquisas Agropecuárias. La Monsanto détient une position hégémonique dans cette réseau d'entreprise.

Mots-clés: Réseau d'entreprises. Restructuration productive. Stratégie des entreprieses.

Resumen: El objetivo de este artículo es analizar la red empresarial de producción de semillas de soja transgénica en el estado de Goiás - Brasil. La principal red de producción de semillas de soja transgénica adaptada al Cerrado brasileño es constituida por la unión entre Monsanto, Embrapa y Centro Tecnológico para Pesquisas Agropecuárias. Se concluye que la Monsanto tiene una posición hegemónica en la red corporativa.

Palabras claves: Red de empresas. Reestructuración productiva. Estrategia empresarial.
\end{abstract}

\section{Introdução}

O mundo globalizado está marcado pelas rápidas e intensas transformações tecnológicas, que tornam os negócios instáveis e incertos. $\mathrm{O}$ ambiente de mudanças requer reformulações das estratégias de produção e distribuição das mercadorias para abrir novas oportunidades de atuação no mercado. A formação de redes de relacionamento inter-organizacional proporciona maior flexibilidade e estabilidade para as empresas atuarem nos mercados globais. Nas mais diversas áreas da economia, desencadeiam-se fusões, incorporações e parcerias empresariais motivadas pela lógica da competitividade e pelas possibilidades das novas tecnologias ampliarem os negócios.

Na produção de biotecnologia moderna orientada para a agricultura, diversas empresas estabelecem relações contratuais de cooperação, com vistas a realizar determinadas etapas do processo produtivo e gerar produtos adequados às diferentes condições ambientais. Gerados à luz do direito internacional, os contratos definem os direitos e obrigações das empresas interligadas na rede, permitindo a previsibilidade do funcionamento da rede empresarial e a legitimação das ações da produção e difusão dos novos produtos biotecnológicos, como a soja transgênica.

Em Goiás, no final da década de 1990, foi construída uma rede de empresas parceiras, composta pela Monsanto, Embrapa e Centro Tecnológico de Pesquisas Agropecuárias (CTPA) para a produção de semente soja transgênica adaptada às condições do clima de cerrado. Cada empresa parceira tem atribuições específicas no processo produtivo, estabelecidas pelos contratos de cooperação.

\footnotetext{
* Mestre em Agronegócios, Professor da Pontifícia Universidade Católica de Goiás. E-mail: lcmoura@live.com ** Doutor em Sociologia, Professor da Universidade Federal de Santa Maria. E-mail: bevilaquamarin@gmail.com
} 
A formação dessa rede empresarial, fundamentada no modelo de acumulação flexível, constituiu-se numa importante estratégia para garantir o domínio no mercado de sementes de soja transgênica na região de cerrados.

Este artigo tem como objetivo analisar a formação das parcerias de empresas para produção de semente de soja transgênica em Goiás, a partir do estudo de caso da rede constituída pela Monsanto, Embrapa, Agência Rural e CTPA, destacando as estratégias de cada empresa no atual contexto da reestruturação da produção capitalista. Para tanto, foram realizadas pesquisas da bibliografia relacionada ao tema e dos documentos produzidos pelas empresas e contratos de cooperação empresarial.

O artigo está dividido em quatro seções interligadas. Na primeira, procura-se contextualizar a reestruturação produtiva, desencadeada pelo processo de globalização da economia, em sua interface com os setores produtivos do agronegócio. A segunda apresenta o quadro de regulamentação dos produtos transgênicos. A terceira analisa as estratégias adotadas pela Monsanto, Embrapa e CTPA para produzir a semente de soja transgênica em Goiás. A última seção enfoca os contratos firmados entre as empresas produtoras de sementes para constituição de uma rede de produção de semente de soja transgênica em Goiás, após a legalização do seu cultivo comercial.

\section{Reestruturação produtiva capitalista e desenvolvimento da biotecnologia}

A globalização está marcada pelos processos de ampliação das interdependências nas relações sociais e econômicas internacionais, que decorrem de a capacidade da economia capitalista ajustar-se às condições de tempo e espaço no processo global de produção e circulação de mercadorias. A interdependência social e econômica se expressa por meio da descentralização industrial e da rapidez proporcionada pelas tecnologias de informação, que facilitam a integração dos capitais industriais, financeiros, comerciais, agrícolas e de prestação de serviços, em processos de produção flexíveis. Portanto a reestruturação produtiva pode ser conceituada como um processo de transformação em escala global, que pode ser notado nos diferentes setores industriais e caracterizado pela influência das tecnologias microeletrônica e informática, pela redefinição das formas de organização produtiva, pela adoção de novos processos produtivos e pelas mudanças nas relações de trabalho (HARVEY, 2001).

O processo produtivo contemporâneo está fundamentado no conhecimento, nas redes de comunicação global, nas tecnologias da precisão e na engenharia genética. $\mathrm{O}$ desenvolvimento de novas tecnologias, principalmente da informática, comunicação e engenharia genética facilitaram os processos de globalização, em suas dimensões econômicas, políticas, tecnológicas e comunicacionais. A globalização está baseada na tecnologia da informação, nas redes de comunicação via satélite e nas empresas transnacionais, além da mobilidade instantânea do capital financeiro e diminuição do poder dos estados nacionais. Como em todas as grandes mudanças da humanidade, traz soluções e mudanças, vantagens e desvantagens: militarização global, crise ambiental, desenvolvimento assimétricos entre as nações, maior controle das transnacionais sobre a economia mundial e diminuição do poder de investimentos do Estado na economia.

Nas primeiras décadas do século XX, o sistema de produção fordista marcou uma nova fase de desenvolvimento do capitalismo. O fordismo ${ }^{1}$ foi caracterizado por ganho de produtividade, economia de escala, rígida burocracia e forte presença do Estado na regulamentação do mercado e na institucio-

\footnotetext{
1 De acordo com Veiga (1997), a expressão "fordismo" surgiu pela primeira vez em Gramsci para designar mais os processos de organização do trabalho industrial que propriamente os modos de consumo. A partir dos trabalhos de Aglietta, o termo foi consolidado com um dos conceitos básicos da Teoria da Regulação: "em Aglietta (1976, p. 96), o fordismo é um novo estágio de regulação do capitalismo. Nesse estágio, a classe capitalista procura gerir a reprodução da força de trabalho assalariada por uma estreita articulação entre as relações de produção e as relações mercantis pelas quais os assalariados compram os seus meios de consumo. O fordismo é, então, uma articulação entre o processo de produção e modo de consumo, constituindo a produção de massa, que, por sua vez, é o conteúdo da universalização do assalariamento" (VEIGA, 1997, p. 65; grifos do autor).
} 
nalização de políticas públicas, conforme as proposições teóricas do economista britânico Keynes. De acordo com Harvey (2001), o fordismo passou a representar "o modo de vida total" do desenvolvimento do capitalismo experimentado no período pós-guerra. Assim, o fordismo passou a ser compreendido não somente como um sistema de produção e organização industrial, mas também como um modo de socialização ou modo de desenvolvimento das sociedades modernas. A expansão do capitalismo pós-guerra estava diretamente associada à ampliação do mercado global. Nesse processo, entraram em cena as empresas internacionais, geralmente com sede nos países desenvolvidos, organizadas em corporações norte-americanas e europeias. Essas empresas multinacionais buscavam mercados mais favoráveis e passaram a explorar a mão de obra local, impondo tecnologias e formas de produção para países dependentes. Progressivamente, essas organizações tornaram-se importantes no desenvolvimento e na expansão capitalista em países como o Brasil.

A partir da década de 1960, segundo Harvey (2001), o fordismo começou se mostrar ineficiente para conter as contradições do capitalismo, pois a manutenção das políticas de bem-estar social tornava-se difícil, devido aos imperativos de redução dos gastos públicos e à rigidez dos investimentos no sistema de produção em massa, que impediam a flexibilidade de planejamento na contratação da mão de obra. A acumulação flexível foi sobrepondo-se ao modelo fordista de produção, induzindo maior flexibilidade na contratação do trabalho, na produção e nos padrões de consumo. A acumulação flexível também abriu espaços para o surgimento de novos setores na economia, pelo mercado financeiro em tempo real e, principalmente, pela inovação das tecnologias e das técnicas gerenciais. A acumulação flexível também foi caracterizada pela instabilidade, pelas incertezas na economia e nas relações sociais, influenciando o padrão de desenvolvimento de várias regiões, aumentando, porém, as desigualdades socioeconômicas. As novas formas de organização empresarial também se caracterizam pela organização descentralizada das unidades produtivas e consequente crescimento da informalidade nas relações de trabalho.
As revoluções nas áreas da informática, da comunicação e da engenharia genética possibilitaram a consolidação do modelo flexível de produção no sistema capitalista. Nesse cenário, as empresas tiveram que rever as formas de administrar os negócios e criar novas estratégias para se adaptar aos novos ambientes, marcados pelas rápidas mudanças, exigências, inseguranças e instabilidades. O tempo e as distâncias diminuíram, devido aos avanços da comunicação via satélite, à diminuição dos custos de transportes e à flexibilidade das empresas em deslocar a sua produção para locais mais favoráveis. Além disso, o setor de serviço adquiriu grande importância no desenvolvimento econômico, da mesma forma que a indústria tinha um papel importante no modo de produção fordista (CASTELLS, 1999).

No que tange ao setor agrícola, as repercussões da reestruturação produtiva podem ser notadas pela construção de novos mercados, pela intensificação das trocas mercantis, pela intensificação da competitividade e pelo desenvolvimento da biotecnologia e tecnologias de precisão, desencadeadas pelas empresas que integram o complexo agroindustrial, vinculadas aos capitais industriais, comerciais, financeiros, agrícolas e de serviços. Poderosas empresas integradas ao complexo agroindustrial tendem a padronizar os processos de produção de bens industriais e agrícolas, bem como monopolizar a produção e comercialização das mercadorias, excluindo dessas relações comerciais contingentes de agricultores e regiões produtoras (RUBIO, 2001).

Segundo Mazzali (2000), as empresas que integram as cadeias produtivas do agronegócio também se adequaram ao novo modelo de produção, baseado na flexibilização e no ambiente mutável e incerto da globalização. O ritmo acelerado do desenvolvimento de novas tecnologias passou a ditar o novo padrão tecnológico-produtivo, desencadeando um ambiente de incertezas ou riscos. $\mathrm{O}$ acelerado desenvolvimento da tecnologia e o encurtamento dos ciclos dos produtos reforçam o grau de incerteza com referência à mudança tecnológica e suas inovações. Para se adaptar a este mundo de incertezas, as organizações empresariais reformularam suas estratégias a partir de sua inserção e atuação 
na atividade produtiva e nos relacionamentos dentro da cadeia produtiva, adaptando a sua gestão interna às alterações na estrutura administrativa, na organização da produção e nos processos de trabalho e condições de trabalho. Em um mundo cada vez mais interdependente, as organizações procuram compartilhar suas estratégias por meio de novas formas de relacionamento, como as alianças estratégicas, joint-venture, fusão e organização em rede.

De acordo com Mazzali e Costa (1997), a organização em rede pode ser considerada como uma estrutura empresarial que utiliza recursos e gestão compartilhados, inserindo atores interdependentes em um ambiente de incerteza e instabilidade. As redes surgem em um contexto global, em que as organizações buscam novos relacionamentos dentro e fora de seu ambiente e a cooperação entre elas é determinante para a minimização de custos e para a sobrevivência dentro do mercado onde atuam.

As mudanças na organização administrativa das empresas estão relacionadas com as recentes transformações tecnológicas. A engenharia genética adquire um papel importante para o desenvolvimento da agricultura, com os organismos geneticamente modificados, a partir de 1996. A formação de um novo paradigma tecnológico, baseado na biotecnologia, está interferindo nos processos de organização da produção e da estrutura internacional, delineando um novo padrão de industrialização e desenvolvimento rural. O setor agrícola deixa de ser altamente dependente do clima, do solo, da qualidade das sementes e, num processo progressivo, torna-se controlado pela informática, pela tecnologia de precisão, pela biotecnologia e pela engenharia genética. Para alguns pesquisadores, esses avanços são avaliados positivamente, pois aumentam a capacidade de dominar o processo da produção agrícola. Para Zylbersztajn, Lazzarini e Machado Filho (1999), a soja transgênica tem a função de aumentar a produtividade e diminuir custos de produção pelo menor uso de agrotóxicos. Caso não produzisse soja transgênica, o Brasil ficaria em situação desfavorável em relação aos seus concorrentes internacionais, que já cultivavam produtos transgênicos, como Estados Unidos e Argentina. Portanto a incorporação de tecnologias transgênicas nos processos produtivos agrícolas tornaria os agricultores e o país mais competitivos no mercado internacional. Contudo os produtores adotariam a tecnologia dos organismos geneticamente modificados, caso a produção de soja transgênica realmente fosse mais vantajosa.

A tecnologia e o capital passam a subordinar, em grande medida, a própria natureza, por meio da reprodução artificial das condições necessárias à produção agrícola, que se tornou dependente das máquinas e dos insumos gerados pela indústria. As pesquisas desenvolvidas na agricultura geraram novas tecnologias, na tentativa de gerar novas máquinas e tecnologias de precisão, suprir as deficiências do solo, prevenir as doenças das plantas, combater as pragas das plantações e produzir sementes com maior produtividade, a fim de aumentar o rendimento por hectare. Com a difusão dessas novas tecnologias, a agricultura tornou-se progressivamente dependente do processo técnico-científico de base industrial (SILVA, 1999).

Surge, então, um novo padrão de produção mais exigente, fundamentado na competitividade e na melhoria da produtividade da agricultura, através dos processos tecnológicos para diminuir os custos de produção agrícola. Aos poucos houve uma modificação no sistema produtivo da agricultura. Mais conhecimentos e informações sobre todo o processo de produção de um determinado produto, assim como a comercialização. Além do conhecimento técnico, é preciso cada vez mais conhecer as formas de se administrar o próprio negócio, principalmente logístico, comércio exterior e marketing. Ocorreu uma transformação na estrutura internacional, desencadeada pelas inovações nos setores da biotecnologia, microeletrônica e informática, que mudou a concepção de produzir, comercializar e distribuir bens, serviços nas cadeias agroindustriais (ELIAS, 2003).

A reestruturação produtiva também trouxe mudanças na organização política e institucional que deu sustentação ao modelo de desenvolvimento econômico e social, experimentado após a Segunda Guerra Mundial. Em meados do século XX, os Estados nacionais e as organizações intergovernamentais exerceram grande influência no desenvolvimento econômico, na institucionalização de políticas públicas e na garantia dos direitos 
sociais. Com a globalização, os Estados nacionais reduziram sua capacidade de intervenção e regulação da economia, enquanto as empresas de capital transnacional passaram a exercer forte influência no desenvolvimento econômico, colocando o poder estatal na contingência de promover mudanças para adequar-se aos novos tempos. Uma alternativa experimentada foi a privatização das empresas públicas, com a transferência da gestão para as empresas de capital privado. A outra foi a formação de parcerias entre o poder público e as empresas de capital privado. Para tanto, foi necessário mudanças nos arcabouços institucionais e jurídicos para garantir o desenvolvimento da iniciativa privada.

\section{Aspectos da regulação dos transgênicos}

Neste contexto da globalização, os países produtores de tecnologias de ponta intensificaram as lutas para o fortalecimento e universalização dos aparatos jurídicos de proteção da propriedade intelectual, com vistas a garantir direitos patentários sobre os novos produtos gerados pelos processos biotecnológicos (WILKINSON; CASTELLI, 2000). No caso das sementes, como destaca Shiva (2001), a internacionalização dos direitos de propriedade intelectual reforça a concepção de que os recursos genéticos são bens de propriedade privada e de elevado valor monetário, em contraposição à condição de bens livres e patrimônio coletivo da humanidade. Para a autora, a criação de um quadro regulatório internacional da produção e comércio de produtos biotecnológicos não visa à preservação ambiental, à biodiversidade e à segurança alimentar. Ao contrário, o direito sobre as patentes constitui-se uma estratégia imposta pelas empresas e organismos internacionais para a privatização da vida e "pilhagem" dos materiais genéticos e do conhecimento das populações do terceiro mundo.

Pessanha e Wilkinson (2005), com base nos estudos de Kloppenburg (1988) e Joly e Ducos (1993), afirmam que o controle e apropriação privada dos recursos genéticos foram desencadeados no início do século XX, a partir da formação de um mercado das variedades geneticamente melhoradas. Aos poucos, surgiram os produtores de sementes melhoradas, que as transformaram em mercadorias de valor elevado. Esse processo engendrou a especialização produtiva, com a separação entre o produtor de sementes e o agricultor, bem como a ruptura entre a semente para a reprodução e o grão para consumo. Mecanismos institucionais e aparatos jurídicos corroboraram para a defesa da apropriação privada das variedades geneticamente melhoradas, configurando uma nova forma reconhecimento dos direitos de propriedade intelectual sobre os recursos de base genética.

De acordo com Pessanha e Wilkinson (2005), os Estados Unidos e países europeus instituíram sistemas particulares de proteção de direitos aos melhoristas de plantas, uma vez que as sementes têm especificidades de mercadorias vivas e que se autorreproduzem. Nos Estados Unidos, foram estabelecidos, na década de 1930, o Plant Protection Act (PPA) para as plantas obtidas pela reprodução assexuada e, na década de 1970, o Plant Variety Protection Act (PVPA) para as variedades comerciais. Na Europa, na década de 1960, foi aprovado o sistema União Internacional para Proteção das Obtenções de Vegetais (UPOV). Já na década de 1980, as empresas que investiam no desenvolvimento de produtos e processos biotecnológicos modernos passaram a pressionar o reconhecimento em todo o mundo dos direitos de propriedade sobre produtores de transgênicos e variedades de plantas geneticamente melhoradas. Os direitos de propriedade intelectual biotecnológica foram reconhecidos inicialmente nos Estados Unidos e logo foram ratificados em outros países desenvolvidos. Com a revisão da Convenção UPOV, realizada em 1991, os direitos dos melhoristas também foram fortalecidos e passaram a ser reconhecidos internacionalmente. A World Intellectual Property Organization (Wipo), órgão vinculado à Organização das Nações Unidas (ONU), instituiu comitês de especialistas para estudo das possibilidades de proteção das inovações tecnológicas e para a mediação do jogo de interesses em torno dos direitos de propriedade intelectual. No entanto, progressivamente, esse debate foi apropriado pelas instituições que regulamentam e controlam as relações do comércio internacional, a exemplo da Rodada do Uruguai do The Agreement on Tariffs and Trade (GATT), que incluiu o grupo de negociação Trade-Related Aspects of Intellectual 
Property (Trips) e da Organização Mundial do Comércio (OMC).

A ingerência dos organismos internacionais resultou na padronização dos aparatos jurídicos de reconhecimento do direito de propriedade intelectual, induzind o o Estado brasileiro a elaborar leis em consonância com as normas do direito internacional (BUAINAIN; CARVALHO, 2000). Dessa forma, a pesquisa, a produção e a comercialização de alimentos transgênicos exigiram a promulgação de novas leis, com o propósito de estabelecer os marcos de regulação das relações comerciais, da preservação ambiental e da segurança alimentar (PESSANHA; WILKINSON, 2003).

Nesse sentido, foi promulgada a Lei n. 11.105, em 24 de março de 2005, conhecida como Lei de Biossegurança, que "estabeleceu normas de segurança e mecanismos de fiscalização de atividades que envolvam organismos geneticamente modificados (OGM) e seus derivados". Sob influência dos marcos legais reconhecidos internacionalmente, o Brasil também promulgou a Lei de Propriedade Industrial (Lei n. 9.279, de 14 de maio de 1996) e a Lei de Proteção de Cultivares (Lei n. 9.456, de 25 de abril de 1997, regulamentada pelo Decreto n. 2.366, de 05/11/1997) para garantir o direito de propriedade intelectual.

A Lei de Propriedade Industrial regula os direitos de proteção de patentes aos produtos e processos industriais e atribui ao Instituto Nacional de Propriedade Industrial funções administrativas dos direitos e concessões relativos à propriedade industrial no Brasil. A lei, em seu artigo 18, inciso III, impede a patente de todo ou parte dos seres vivos, sejam plantas ou animais, bem como microorganismos encontrados na natureza. Mas a lei permite o patenteamento de "microorganismos transgênicos que atendam aos três requisitos de patenteabilidade: novidade, atividade inventiva e aplicação industrial". O texto da lei define que "microorganismos transgênicos são organismos, exceto o todo ou parte de plantas ou de animais, que expressem, mediante intervenção humana direta em sua composição genética, uma característica normalmente não alcançável pela espécie em condições naturais". O artigo 42 garante amplos direitos para o titular da patente impedir que terceiros produzam, usem, vendam ou importem o produto patenteado. Em caso de exploração indevida do produto, o artigo 44 assegura que o titular da patente tem direito de obter indenização pela exploração indevida de seu objeto, "inclusive em relação à exploração ocorrida entre a data da publicação do pedido e a da concessão da patente". Dessa forma, os produtos obtidos por meio de processo biotecnológico patenteado estão sujeitos aos direitos exclusivos do detentor da patente. Vale ressaltar que essa lei regulamenta o processo biotecnológico da criação da soja transgênica no Brasil, garantindo direitos ao processo utilizado para introduzir o gene resistente ao glifosato nas cultivares de soja.

A Lei de Proteção de Cultivares determina formas, objetivos e prazos de proteção para os melhoristas, bem como cria o Serviço Nacional de Proteção de Cultivares (SNPC), com responsabilidade pela emissão dos certificados de proteção. $\mathrm{O}$ artigo $2^{\circ}$ estabelece que:

[...] a proteção dos direitos relativos à propriedade intelectual referente a cultivar se efetua mediante a concessão de Certificado de Proteção de Cultivar, considerado bem móvel para todos os efeitos legais e única forma de proteção de cultivares e de direito que poderá obstar a livre utilização de plantas ou de suas partes de reprodução ou de multiplicação vegetativa, no País.

Atendidos os critérios de obtenção de propriedade intelectual, a lei fixa um prazo de quinze anos de proteção para as cultivares e estabelece direitos exclusivos sobre a reprodução comercial da variedade protegida, interditando a produção comercial em território brasileiro, sem a autorização do titular da variedade. Contudo a lei assegura que as cultivares protegidas podem ser utilizadas para reserva e plantio para uso próprio, consumo e venda como alimento ou matéria-prima, bem como para variação no melhoramento genético ou na pesquisa científica. Ao pequeno produtor rural e suas associações, a lei também garante o direito de multiplicação de sementes para fins de doação ou troca para outros pequenos produtores rurais, nos programas governamentais de desenvolvimento rural.

Vale ressaltar que as leis de Proteção da Propriedade Industrial e de Proteção de Cultivares constituem o aparato legal que orienta a elaboração dos contratos de produção de soja transgênica no Brasil. A primeira garante 
direitos à empresa detentora do gene da soja transgênica, enquanto a segunda protege os direitos da empresa proprietária de variedades adaptadas ao cerrado.

A organização de uma rede empresarial para a produção de semente de soja transgênica, que se configurou no Estado de Goiás, pode ser considerada um caso emblemático das transformações socioeconômicas pelas quais passa a agricultura, no atual contexto da reestruturação produtiva e do crescimento da biotecnologia, como os produtos transgênicos.

\section{Estratégias das empresas produtoras de semente de soja}

Em Goiás, a principal rede empresarial de produção de semente de soja transgênica está organizada no "Convênio Cerrados", cujos signatários são a Monsanto, a Embrapa e o CTPA. Esse convênio interligou diversas instituições privadas e públicas, sob a hegemonia da Monsanto e da Embrapa, cujas relações interinstitucionais estão reguladas por contratos que estruturam o sistema de produção de semente de soja, com o objetivo de promover o melhoramento genético e biotecnológico das cultivares adaptadas às condições edafo-climáticas da região do cerrado do Brasil.

A Monsanto é uma empresa transnacional de capital americano, fundada em 1901, com sede em St. Louis, Missouri. Em sua trajetória de diversificação produtiva, a Monsanto deixou para um segundo plano o seu principal negócio - o químico -, em proveito de atividades mais rentáveis, dinâmicas e inovadoras - a chamada "ciência da vida". A substituição não enfraqueceu os conhecimentos existentes na empresa, ao contrário, o processo de diversificação desencadeou-se a partir das competências existentes, pois a engenharia genética foi absorvida como ativo complementar à agroquímica, permitindo a conjugação dos negócios químicos com a produção de sementes transgênicas. No entanto o fator que incentivou a empresa a entrar no ramo da biotecnologia foi o prolongamento dos direitos de propriedade intelectual do herbicida Roundup, cuja patente estava expirando. Para evitar que outras empresas utilizassem a sua versão genérica do produto, a Monsanto investiu em pesquisa de plantas resistentes ao Roundup, produzindo um pacote tecnológico que consistia na venda das sementes transgênicas junto com o herbicida Roundup (GUERRANTE, 2003).

Em 1951, a Monsanto iniciou as suas atividades no Brasil e, em 1970, sintetizou o glifosato, princípio ativo utilizado no herbicida Roundup. Registrado em 120 países, o Roundup é o produto químico mais vendido no mundo para o controle de plantas daninhas em préplantio e no plantio direto das lavouras, daí que o herbicida revolucionou a agricultura, desde que entrou no mercado. Inicialmente, todo o produto comercializado no Brasil era importado e, a partir de 1984, o Roundup passou a ser produzido nacionalmente, quando foi instalada a primeira fábrica em São José dos Campos. No Brasil, a marca Roundup se transformou num mix de produtos: o Roundup Original, produto pioneiro que passou a ser designado dessa forma em 1999; o Roundup WG, tecnologia granulada, lançada em 1997; e Roundup Transorb, que faz com que o produto chegue mais rápido e em maior quantidade à raiz da planta daninha.

A partir de 1981, a Monsanto começou a investir em biotecnologia e logo se tornou o foco principal de pesquisa da empresa. Para tanto, entre 1995 a 1997, adquiriu as empresas Calgene, Asgrow, Monsoy, Dekalb e Agroceres; em 2001, inaugurou, em Uberlândia, o maior complexo de semente de pesquisa de sorgo e milho; em 2005, anunciou a compra da Seminis, maior produtora de sementes de hortaliças, bem como da Emergent Genetics, empresa de semente de algodão. A Monsanto possui duas unidades industriais, cinco escritórios regionais de vendas e doze unidades de pesquisa, armazenagem e processamento de sementes. No Estado de Goiás, possui uma unidade de pesquisa em Morrinhos, orientada para a produção e pesquisa de sementes de soja, inclusive transgênicas, e outra em Santa Helena de Goiás, voltada para a pesquisa milho e sorgo, agroquímicos e biotecnologia. Além disso, estabeleceu um escritório comercial em Goiânia. A Monsoy - antiga FT Sementes - é uma empresa do grupo Monsanto, responsável pela produção e comercialização de sementes certificadas de soja, tanto de variedades quanto de transgênica. Em Goiás, a Monsoy possui uma densa 
rede de distribuidores e multiplicadores por todo o Estado, dentre elas a Selecta, um dos cotistas do CPTA. A Monsanto tem um serviço diferenciado de assistência técnica pré e pós-venda, que oferece orientação aos agricultores durante o ciclo produtivo até o momento da venda da soja (SANTINI; PAULILLO, 2003; MONSANTO, s.d.).

Desde 1995, a Monsanto vem adquirindo outras empresas do ramo de semente no Brasil, entre as quais se destacam a Agroceres, do setor de semente de milho e sorgo. Em 1997, adquiriu a FT Sementes, criando a Monsoy, conquistando, assim, sua posição hegemônica no mercado de sementes e agroquímicos. A aquisição da FT Sementes foi uma estratégia mercadológica importante para a Monsanto, tendo em vista a ampliação de seu banco de germoplasma, com cultivares adaptadas às condições edafo-climáticas brasileiras, em conformidade e atendimento da Lei de Proteção de Cultivares vigente no Brasil.

Assim, a aquisição dessa empresa foi estratégica, uma vez que a Monsanto não possuía experiência no ramo de semente, muito menos detinha a tecnologia das cultivares adaptadas às condições edafo-climáticas da agricultura tropical brasileira. A empresa realizou altos investimentos em biotecnologia, mas ficou dependente de cultivares desenvolvidas por outras empresas para inserir o seu gene transgênico. Entretanto as estratégias adotadas pela Monsanto, nos últimos anos, condizem com as necessidades de produzir novas tecnologias em áreas afins, com o objetivo de criar posições competitivas no mercado. As buscas por essas habilidades complementares induzem as empresas a criarem grandes projetos de pesquisa, sob formas de redes e comércios com outras empresas, instituições públicas de ensino e de pesquisa (SANTINI; PAULILLO, 2003).

A Monsanto utiliza diferentes estratégias de venda em seus mercados de atuação. A estratégia de produção de sementes de milho (Agroceres) é diferente da estratégia de produção de semente de soja, na qual é forte a presença da Embrapa. Além disso, a empresa atua no licenciamento da soja transgênica e, até o momento, detém sozinha a tecnologia da soja geneticamente modificada. Existe uma estrutura criada para cobrar os royalties pelo uso da nova tecnologia. Legalmente, a soja transgênica foi comercializada a partir da safra de 2004/2005, o que exigiu a criação de uma estrutura de pagamento dos royalties muito diferente do que é utilizado em outros países pela Monsanto. A princípio, a cobrança gerou um ambiente de incertezas entre os produtores, e a Monsanto procurou propor uma forma que não fosse tão onerosa para os produtores de semente.

No Brasil, a Monsanto exige dos multiplicadores de semente que administrem o Sistema de Pagamento dos Royalties por parte dos agricultores. Ao comprar as sementes transgênicas, o agricultor deverá fornecer, para um sistema eletrônico, os seguintes dados: CPF ou CGC, cadastro do produtor, volume e tipo de semente adquirida. Todas as informações estarão disponíveis aos participantes do sistema de cobrança, desde multiplicadores licenciados até os traders, cerealistas e cooperativas, no momento da entrega, comercialização da produção e compra de sementes. Todos os agricultores que ultrapassarem o "crédito de produção", chamado no contrato de "bônus", ou que não tenham registro em seu sistema de cobrança, ficam obrigados a pagar uma indenização à Monsanto no ato de comercialização de sua produção.

Por meio CPF ou CGC do produtor, pode-se verificar se ele efetuou ou não o pagamento de royalties, quando a soja é vendida aos compradores de grãos. Caso não tenha efetuado o devido pagamento, o produtor não poderá vender a soja, com a possibilidade de os compradores sofrerem sanções por parte da Monsanto. Forma-se uma parceria às avessas, criando uma estrutura de cobranças nas empresas produtoras e distribuidoras de sementes, por meio de um sistema eletrônico bastante eficiente de fiscalização dos pagamentos dos royalties e de transferência de responsabilidades para as empresas parceiras.

Para tecer essa rede empresarial, foi utilizado um acordo de licenciamento com a Embrapa, no qual se estruturou um conjunto de cláusulas com direitos e deveres. O acordo tornou-se importante para dar maior segurança na relação da Monsanto com os produtores ou vice-versa. As negociações demandaram muito tempo, pois a Monsanto estava impondo a sua vontade sobre os produtores. Mesmo 
como única fornecedora da tecnologia da soja transgênica, ela não teve capacidade de impor de forma extensiva, exigindo dela maior flexibilidade para formar redes com empresas que já produziam variedades de soja adaptadas às diversas regiões do Brasil.

Assim, para difundir a soja transgênica adaptada à região do Cerrado, a Monsanto teve que firmar contratos de licenciamento de sua tecnologia para a Embrapa. Esta é uma empresa pública, vinculada ao Ministério da Agricultura, Pecuária e Abastecimento (MAPA), com atuação na pesquisa e desenvolvimento de sementes básicas, matériaprima para a produção da semente certificada e fiscalizada. Está sob sua coordenação o Sistema Nacional de Pesquisa Agropecuária (SNPA), centro de uma densa e complexa rede de pesquisa e desenvolvimento descentralizada, espalhada por todo o Brasil, na qual pesquisadores, técnicos e instituições parceiras desenvolvem pesquisas direcionadas às diferentes realidades da agricultura brasileira, tornando a agropecuária competitiva. Esse salto tecnológico só foi possível através de parcerias da Embrapa com outras instituições, formando estrategicamente uma grande network de pesquisa em melhoramento genético, principalmente no segmento da pesquisa da soja, realizado pela Embrapa Soja em Londrina, Paraná. Essa unidade foi importante para as adaptações das cultivares aos diferentes climas e solos do Brasil, em especial na grande área dos cerrados, atualmente a principal região brasileira produtora de soja. Isso foi possível devido às inúmeras parcerias estabelecidas pela política de negócios existentes na empresa.

A Embrapa defende a construção de parcerias para o melhoramento de variedades de plantas, por meio da pesquisa e desenvolvimento, em conformidade com a política de negócios tecnológicos da empresa: "é fundamental que todas as unidades operacionais estabeleçam o maior número de parcerias internas e externas à empresa como forma de complementar os recursos humanos, financeiros e assim multiplicar a oferta e a capacidade de transferência de tecnologia" (EMBRAPA, 1998, p. 25).

Estrategicamente, a formação de uma rede de empresas parceiras tornou-se importante para viabilizar a missão da empresa, que é o desenvolvimento de pesquisa na agropecuária para a realidade socioeconômica e ambiental do Brasil. As parcerias desenvolvidas pela Embrapa são realizadas em torno das fundações de direito privado, com o objetivo de desenvolver, produzir e licenciar novas cultivares de plantas. Essas fundações dão flexibilidade aos parceiros em termos de licenciamento das cultivares, alocação e utilização de recursos financeiros, humanos e materiais. As interações entre a empresas parceiras são especificadas nos contratos, delimitando direitos e obrigações dos signatários, com vistas a diminuir as incertezas no relacionamento da parceria (CARVALHO, 2005).

Segundo Miranda (2005), a Embrapa Soja criou o "Sistema Embrapa de Parcerias", responsável pelo estabelecimento de redes de cooperação empresarial, envolvendo instituições públicas e privadas. A principal característica desse sistema foi a estruturação de redes ou networks com o setor privado, uma vez que os recursos públicos para o desenvolvimento de ciência e tecnologia tornaram-se escassos. No entanto, ao longo do tempo, a Embrapa conquistou uma participação importante no mercado brasileiro de sementes de soja, alcançando em torno de $75 \%$, em 1998. A aprovação das leis de Propriedade Industrial e de Proteção de Cultivares levou a empresa a estabelecer três modalidades de parcerias empresariais. A primeira modalidade de contrato é uma cooperação técnica a partir do planejamento dos cruzamentos, na qual o parceiro tem que contar com uma equipe técnica capacitada, com programa de melhoramento próprio e participação do parceiro público na geração de uma nova cultivar. Nesse caso, a Embrapa admite cotitularidade do parceiro público sobre a propriedade intelectual da cultivar obtida no âmbito de parceria, e os benefícios comerciais serão rateados. Além disso, fica concedido à parceria privada o direito de exploração comercial da cultivar por dez anos. A segunda modalidade é uma cooperação técnica a partir de linhagens, quando o parceiro privado e a Embrapa desenvolvem juntos as cultivares de soja, recebendo material genético e realizando testes necessários para uma eventual exploração comercial. A Embrapa tem o direito exclusivo sobre a propriedade intelectual, ficando ao parceiro privado a ex- 
clusividade na exploração comercial por oito anos, com a possibilidade de sublicenciar. A terceira modalidade prevê uma cooperação financeira, na qual o parceiro fornece recursos financeiro e pessoal para o desenvolvimento das pesquisas da Embrapa. O parceiro poderá multiplicar e comercializar exclusivamente as cultivares, fruto do convênio, por um tempo a ser definido caso a caso.

Dessa forma, a Embrapa procura estabelecer parcerias com diversas instituições - atualmente estão em vigor mais de 1.500 convênios e contratos -, envolvendo empresas públicas de pesquisa e de extensão, prefeituras e secretarias de agricultura, universidades, cooperativas, sindicatos, organizações não governamentais, associações, fundações e empresas privadas. Além disso, a Embrapa desenvolve parcerias importantes com as fundações privadas de apoio à pesquisa e ao desenvolvimento e de produtores de sementes. Atualmente, são muitas as fundações que mantêm convênios e contratos com a Embrapa, com destaque para aquelas voltadas para os programas de melhoramento genético de grãos conduzidos pela Embrapa, que conferem maior flexibilidade às ações, fazendo com que seu trabalho esteja presente nos pontos do país onde seria oneroso manter infraestrutura própria.

Atualmente, existem oito fundações no Brasil que, com outros parceiros, compõem uma rede de pesquisa na área de melhoramento genético de soja (EMBRAPA, 2006).

A pesquisa agropecuária, em Goiás, começou em 1975, por meio de uma parceria entre a Embrapa e a antiga Empresa de Pesquisa Agropecuária do Estado de Goiás (Engopa). Na década de 1990, devido à crise financeira e à redução da participação estatal no financiamento da pesquisa, houve a necessidade de ampliar os trabalhos em redes empresariais para agregar maior número de parceiros. Na época, a escolha recaiu para a Associação Goiana de Produtores de Sementes (Agrosem), mas houve dificuldade na operacionalização da parceria. Em 1997, foi fundado o CPTA com o caráter de uma sociedade limitada centrada na pesquisa da soja. Todos os recursos captados pelo CTPA, através de taxa tecnológica e cotas, são aplicados na pesquisa da soja, sendo que, em 2005, foram investidos cerca de $\mathrm{R} \$ 5$ milhões.
O CTPA é formado por, aproximadamente, trinta empresas, que se constituem em sócio-cotistas produtoras de sementes, oriundas de várias partes do Brasil: 23 de Goiás, duas de São Paulo, uma do Distrito Federal, uma de Minas Gerais, uma do Paraná, uma Santa Catarina e uma do Tocantins. Existe, portanto, uma densa rede de empresas que se uniram para produzir sementes de soja transgênica no cerrado brasileiro. A ampla rede de sócio-cotistas é importante para a Embrapa para utilizar as estruturas econômica e financeira destas empresas, dando maior competitividade ao mercado. Em contrapartida, as empresas sócias do CTPA podem usufruir da experiência em pesquisa desenvolvida pela Embrapa.

O CTPA mantém três contratos: o primeiro, firmado com a Agência Goiana de Desenvolvimento Rural e Fundiário (AgenciaRural), tem por objetivo produzir cultivares de soja convencional; o segundo, firmado com a Embrapa e AgenciaRural, também objetiva a produção de cultivares de soja convencional; o terceiro, firmado com a Embrapa, visa à cooperação técnica e financeira (RETEC, 2002). A vantagem dessa parceria é a utilização dos pontos de testes dos experimentos que são conduzidos pela Embrapa e realizados nas fazendas dos cotistas em vários estados. Ao invés de fazer plantio nas estações experimentais, os ensaios são conduzidos nas próprias fazendas, possibilitando escolher melhor os materiais mais estáveis para cada região, já que os dados são observados levando-se em conta as condições da propriedade.

O Convênio Cerrados é outra parceria que agrega as forças da Embrapa, da AgenciaRural e do CPTA. Este contrato nasceu da discussão sobre a capacidade da pesquisa de organizar, prever e dar soluções para o sistema de produção da soja, visando à produção de semente de novas cultivares e tecnologias que possam viabilizar a melhor forma de produzir soja. Essas cultivares têm origem no banco de germoplasma da Embrapa e da AgenciaRural de Goiás, que contam com uma experiência de mais de 30 anos na produção de cultivares de soja adaptadas às regiões de Cerrado. 


\section{Contratos de cooperação técnica: a rede Monsanto, Embrapa e CTPA}

De acordo com Zylbersztajn (2005, p. 395), “a indústria de semente é fortemente baseada em contratos de licenciamento entre as organizações detentoras de tecnologia e os multiplicadores". Os contratos de licenciamento definem os direitos e obrigações de cada empresa integrante da rede, combinando recursos humanos, financeiros e tecnológicos para lidar com um ambiente de incertezas e riscos provocado pela reestruturação produtiva. Além de tecer rede de empresas parceiras, as estruturas legais e institucionais aumentam a previsibilidade e confiança no relacionamento e reduzem os riscos e conflitos.

Vale lembrar-se de que as leis de propriedade industrial e de cultivares regulam os processos de produção da soja transgênica e os termos contratuais firmados entre as empresas parceiras interessadas em atender o mercado da região de cerrado. Assim, as relações de produção, distribuição e comercialização de sementes de soja transgênica estão estruturadas em torno dos contratos de licenciamento, que estabelecem as atribuições de cada empresa interligada na rede.

A Monsanto é detentora da tecnologia da soja transgênica, que apresenta resistência ao herbicida glifosato. Por ser um organismo geneticamente modificado, a soja transgênica é regulamentada pela Lei de Propriedade Industrial. Já a Embrapa detém a propriedade de cultivares adaptadas às condições edafo-climática de Goiás, o que lhe confere o direito de proteção das cultivares, tanto na produção e quanto na comercialização. Tendo em vista as diferentes tecnologias e suas leis de proteção, diversas empresas privadas produtoras de semente criaram o CTPA, com o propósito de formar uma rede de empresas com competitividade para atuar no mercado de produção de soja transgênica na região de cerrados brasileiro. Com isso, conseguiram firmar contrato de parceria com a Embrapa, denominado Convênio de Cooperação Técnica e Financeira. Em parceria, a Embrapa e o CTPA desenvolvem pesquisas para viabilizar a produção de semente de soja transgênica em Goiás, uma vez que a Embrapa licencia as suas cultivares, e o CTPA entra com os produtores e os recursos financeiros. Nessas relações contratuais existem atribuições prédeterminadas na divisão de trabalho para a produção da soja transgênica, bem como interdependências entre essas organizações que conferem competitividade às empresas, ao mesmo tempo em que garantem a continuidade dos processos de inovação da sua base tecnológica.

Em 1997, foi celebrado o contrato de cooperação técnica entre a Monsanto e a Embrapa para a pesquisa e produção de semente transgênica. $O$ contrato ocorreu entre duas organizações que têm objetivos mercadológicos e sociais diferentes. Quando a Monsanto firmou o contrato com a Embrapa, houve, por parte do governo brasileiro, uma opção pela tecnologia dos transgênicos e na defesa do princípio da equivalência substancial, segundo o qual não há diferenças substanciais e nutricionais entre os produtos geneticamente modificados e os produtos convencionais. Sendo substancialmente equivalentes, os transgênicos não seriam prejudiciais à saúde e ao meio ambiente. Assim sendo, o acordo legitimou a hegemonia da Monsanto e a sua tecnologia como algo imprescindível para os agricultores brasileiros, abrindo espaços para a ampliação do mercado de atuação da transnacional de origem americana, dentro dos marcos legais do Brasil. A Monsanto provocou grandes mudanças no setor de sementes de soja no Brasil, uma vez que é detentora única da tecnologia da soja geneticamente modificada, sendo responsável por $66 \%$ das cultivares transgênicas. Na época em que foi firmado Contrato Embrapa-Monsanto, cerca de $70 \%$ da área plantada com soja no Brasil eram com variedades produzidas pela Embrapa. Dessa forma, a Embrapa constitui-se uma empresa estratégica para se firmar um contrato de parceria.

A Embrapa e a Monsanto assinaram o primeiro contrato em 22 de abril de 1997, com o objetivo de "desenvolver cultivares de soja tolerantes ao herbicida Roundup", com vigência de três anos. Esse contrato foi prorrogado em 30 de março de 2000, acrescentando como objeto a exploração comercial da soja transgênica, utilizando as cultivares da Embrapa e a tecnologia dos transgênicos da Monsanto. Além disso, houve dois Termos Aditivos firmados em 30 de março de 2000 e 31 de julho de 2002. 
No primeiro contrato de 1997, a Embrapa era obrigada a utilizar somente o herbicida fornecido pela Monsanto: “A Embrapa usará apenas herbicida à base de Glifosate de marca Roundup para avaliar as linhagens e cultivares de soja transgênica ao Roundup [...]". Esta cláusula do contrato obrigava a Embrapa a utilizar somente o herbicida da Monsanto, infringindo, assim, a livre concorrência. $\mathrm{O}$ Conselho Administrativo de Defesa Econômica (CADE) sugeriu uma modificação no texto, que foi consubstanciada no Termo Aditivo n. 2, de 31 de julho de 2002: "visando substituir no texto do contrato ora aditado toda e qualquer indicação de marca de herbicida por seu princípio ativo".

Como se pode observar, a Monsanto garantiu hegemonia na elaboração dos contratos. Todavia esses acordos possibilitaram à Embrapa o acesso legal não somente para pesquisa como também para comercializar exclusivamente as suas cultivares transgênicas, inclusive para os seus parceiros, desde que estes assinassem um contrato de licenciamento com a Monsanto. O contrato foi importante devido à credibilidade e à qualidade das cultivares da Embrapa, o que legitimou a tecnologia transgênica da Monsanto perante os produtores de semente, tornando-se uma grande divulgadora dessa nova tecnologia, com a utilização das suas cultivares adaptadas praticamente em todas as grandes regiões produtoras de soja do Brasil.

Os contratos entre a Embrapa e a Monsanto receberam várias críticas devido às vantagens que a Monsanto teria perante a empresa pública brasileira. Diante disso, a Embrapa se manifestou oficialmente para esclarecer os principais pontos polêmicos. Com base em estudos sobre construção gênica da soja resistente ao herbicida à base de glifosato, a Embrapa concluiu que a tecnologia da Monsanto é eficiente tecnicamente. Com base nesses resultados, decidiu-se desenvolver cultivares de soja transgênica, resistentes ao herbicida à base de glifosato, que são protegidas em nome exclusivo da Embrapa. Também se acrescentou que ela não está licenciando seu germoplasma para a Monsanto, mas a Monsanto está licenciando a sua tecnologia de soja transgênica. Os parceiros da Embrapa não podem ser recusados pela Monsanto. A proteção exclusiva significa que a Embrapa é quem decide o que e onde produzir, quanto produzir e quem deve produzir. A taxa tecnológica a ser negociada e cobrada pela Monsanto dos parceiros da Embrapa não pode ser maior do que a cobrada de outros parceiros diretos da própria Monsanto. Foi assegurado que qualquer agricultor poderá guardar sementes para uso próprio em novo plantio, de acordo com a Lei de Proteção de Cultivares. A Embrapa mantém programa de melhoramento da soja convencional e convênios de pesquisa com outras empresas de biotecnologia, visando criar alternativas para os produtores. Acrescenta ainda que o seu banco de germoplasma é instrumento fundamental de negociação, pois, sendo de domínio de uma instituição pública, permite dar suporte e fortalecer a indústria nacional de sementes, contribuindo para sua competitividade. Ela justificou as parcerias com as transnacionais que detenham tecnologia de interesse para o país, mas que seja garantido o controle do material genético pelas instituições públicas (EMBRAPA, 2006).

Nesse contrato, tem-se de um lado a Monsanto, empresa transnacional americana, presente em todo o mundo, com o objetivo principal do lucro. Ela não prioriza os aspectos sociais, mas tem uma contínua preocupação com o lucro, mesmo porque, se não fosse assim, não teria como sobreviver. A transnacional tem uma imagem bastante negativa perante os ambientalistas, consumidores e até mesmo entre alguns de seus parceiros. A Embrapa, sendo uma empresa pública voltada para o desenvolvimento da pesquisa agropecuária, tem grande preocupação pelos aspectos sociais e não é somente uma propaganda mercadológica, como ocorre com a Monsanto. A Embrapa foi e continua sendo uma empresa muito importante na criação de novas tecnologias para os agricultores brasileiros. Por ser uma empresa pública, a Embrapa tem o dever com a ética e transparência em suas ações, principalmente quando desenvolve parcerias com as empresas do setor privado que têm uma conduta de negócio baseada no lucro.

De modo geral, a Embrapa justificou o seu acordo com a Monsanto, tranquilizando ao público que o seu banco de germoplasma não será utilizado pela Monsanto e as pesquisas não estarão restritas apenas à soja transgênica. Além do mais, os seus parceiros poderão 
utilizar as suas cultivares transgênicas, desde que sejam licenciadas pela transnacional. Pode-se observar que as sojas transgênicas vêm sendo pesquisadas e lançadas com maior frequência no mercado: cerca de 10,85\% de todas as cultivares da Embrapa com os seus parceiros são transgênicas, segundo os dados da SNPC, do MAPA (2006). Esse percentual tende a aumentar, a partir do momento em que houver uma consolidação da tecnologia transgênica no Brasil. Nesse caso, a Embrapa contribui muito com a disseminação da soja transgênica e com o lucro da Monsanto, pois todos devem pagar royalties para produzir a soja transgênica, mesmo utilizando as cultivares da Embrapa, que são de reconhecida qualidade e respeitabilidade no mercado. Algumas partes dos contratos são questionáveis devido a sua rigidez com a Embrapa, como pode ser observado na cláusula 8 do contrato de cooperação técnica, de 22 de abril de 1999:

As partes obrigam-se, por si ou através de seus diretores, administradores, empregados, prestadores de serviços ou prepostos (doravante denominados 'REPRESENTANTES') manter o mais completo e absoluto sigilo em relação a toda e qualquer 'INFORMAÇÃ O' relacionada às atividades da outra parte e/ou de suas envolvendo as partes e/ ou de suas subsidiárias ou, ainda, de terceiros, das quais venham a ter conhecimento ou acesso por força do 'PROGRAMA', não podendo, sob qualquer pretexto, utilizá-las para si, divulgar, revelar, reproduzir ou de qualquer maneira delas dar conhecimentos a terceiros, responsabilizando-se, em caso de descumprimento desta obrigação assumida, por eventuais perdas e danos e demais cominações legais.

Nesses termos, as relações contratuais tendem a restringir o acesso aos resultados das pesquisas e as informações de interesse social para o país e a limitar a autonomia da pesquisa da Embrapa. Indubitavelmente, esses condicionantes submetem os interesses da empresa pública aos propósitos da transnacional americana. A questão que emerge dessa parceria é: até que ponto esse relacionamento entre o público e o privado apresenta-se benéfico para a sociedade e não somente a uma determinada empresa (Monsanto) ou a um grupo de empresas (CTPA)?

Não se pode negar que existe um novo contexto provocado pela reestruturação produtiva capitalista, que obriga as organizações públicas a buscar novas formas de financiamento e de parcerias para tornaremse competitivas e trazerem soluções para a sociedade. A soja transgênica foi aprovada comercialmente nos Estados Unidos, em 1996, e, após um ano, a Embrapa assinou um acordo de cooperação técnica com a Monsanto, sem saber ao menos as consequências da nova tecnologia ou mesmo se seria aprovada comercialmente no Brasil. Somente em 2005 houve aprovação definitiva para a produção comercial da soja transgênica no Brasil, e ainda não é possível vislumbrar ações concretas em prol da sociedade com o acordo entre a Monsanto e a Embrapa, principalmente no tocante à soja transgênica, que é uma tecnologia voltada para os grandes produtores de soja do Centro-Oeste.

Nesse contexto, criou-se uma rede de produtores de sementes de soja através desses contratos. As parcerias surgiram através de contratos de licenciamento realizado em dois momentos: primeiro com a Monsanto, na licença da utilização da tecnologia transgênica, e depois, quando os parceiros da Embrapa pagam um royalty no valor de $5 \%$ da produção. Segundo o contrato da Embrapa Transferência Tecnológica de Goiânia com o CTPA, “a exploração comercial por terceiro de cultivar Embrapa, no Brasil, será feita por intermédio de contratos de licenciamento firmados com produtor de semente, separadamente, pela Embrapa e pela Monsanto [...]". São dois contratos distintos de licenciamento: um envolve a Monsanto (detentora da tecnologia para a soja transgênica) e os produtores sócios cotistas do CTPA, e o outro a Embrapa (detentora das cultivares de soja) e os produtores sócios cotistas do CTPA. Nessas relações contratuais entre as empresas e os produtores, nasceram as parcerias ou, mais especificamente, as redes de produção de soja transgênica em Goiás.

O Contrato de Cooperação TécnicoFinanceira para a produção de soja transgênica, firmado entre a Embrapa e o CTPA, em 31 de agosto de 2004, estabelece o direito de os sócios cotistas do CPTA usarem a semente de soja com exclusividade, para fins de multiplicação e comercialização pelo prazo de oito anos; que a Embrapa é detentora das cultivares de soja geneticamente modificada e resistente ao herbicida à base de glifosato e 
que a multiplicação de semente básica de soja transgênica será realizada por conta e risco dos cotistas, mas terá orientação da Embrapa.

Ainda no tocante a esse contrato, a Embrapa tem a obrigação de fornecer as sementes básicas, realizar a embalagem e beneficiamento da semente básica produzida. O cotista do CTPA tem as obrigações de instalar os campos de produção, promover por sua conta e risco as colheitas, permitir o acesso dos técnicos da Embrapa para acompanhar a produção e a colheita, manter sigilo sobre todas as informações técnicas vinda da Embrapa e cumprir a legislação referente à produção de semente de soja transgênica.

O contrato entre a Embrapa e o CTPA também prevê investimentos financeiros para o desenvolvimento de pesquisas. De um lado, o CTPA fornece os recursos financeiros para o custeio da pesquisa, a propriedade rural, as máquinas, equipamentos e insumos, os recursos humanos para desenvolver as pesquisas e comercializar as sementes e recolher os royalties da Embrapa, que gira em torno de $5 \%$ para os seus cotistas. Em contrapartida, a Embrapa deve fornecer as sementes básicas, os técnicos e os conhecimentos sobre a tecnologia da soja transgênica. Os sócios cotistas do CTPA têm a incumbência de multiplicar as sementes de soja transgênica e, posteriormente, comercializá-las aos agricultores, por meio de uma rede própria de distribuição. $\mathrm{O}$ CTPA tem as instalações em Goiânia, dentro de uma área da Embrapa, que possibilita uma contínua troca de informações entre os seus técnicos para operacionalizar os vários acordos de parcerias existentes entre eles.

Nessas condições, o sistema de parcerias instituído pela Embrapa visa dar competitividade à produção de soja transgênica e facilitar a transferência de tecnologias para outros segmentos da sociedade. Tornou-se relevante a presença do CPTA na multiplicação da semente de soja transgênica em Goiás, já que, financeiramente, a Embrapa teria dificuldades em operacionalizar a sua pesquisa, pela redução de verbas. Além disso, a Embrapa conta com uma boa infraestrutura para experimentar suas cultivares nas fazendas dos cotistas do CPTA, que, tecnicamente, são melhores que os seus campos de experimentação.

Em contrapartida, o CPTA tem vantagens ao ingressar na rede de cooperação para produção de semente de soja, seja convencional, seja transgênica, que podem ser notadas desde a possibilidade de instalar o seu escritório no espaço físico da Embrapa Escritório de Transferência de Tecnologia de Goiânia -, até a manutenção de três contratos, com destaque para o Contrato de Cooperação Técnica e Financeira com a Embrapa. A partir desse contrato, ambas as instituições vêm pesquisando na área da soja transgênica, lançando na safra 2004/2005 e 2005/ 2006 quatro cultivares de soja transgênica, direcionadas ao mercado goiano.

Dessa forma, as parcerias são importantes para o CPTA ter acesso a uma tecnologia avançada, como é o caso da soja transgênica, bem como ter uma agilidade maior em obter novas cultivares. Por meio dos contratos de cooperação técnica, os empresários cotistas do CTPA podem acessar tecnologias de ponta disponibilizada pela pesquisa pública e privada, com margens para escolher entre a multiplicação de semente de soja convencional ou transgênica.

\section{Considerações finais}

No atual contexto de reestruturação produtiva, as empresas organizam-se em redes de produção, com vistas a garantir a competitividade e superar as instabilidades geradas pela globalização. Em um ambiente de rápidas mudanças e de acentuada concorrência, uma forma de manter-se no mercado e ampliar os negócios é através da formação de parcerias e criação de redes de empresas.

O desenvolvimento dos transgênicos implica altos investimentos e riscos de perdas financeiras, pela possibilidade de a nova tecnologia não ser incorporada nos sistemas produtivos e nos mercados consumidores, devido às questões econômicas, técnicas, sanitárias, ambientais, legais ou éticas. Tais problemas impõem às empresas produtoras de biotecnologias a adoção de várias estratégias para garantir a difusão dos transgênicos, a começar pela posição política de interferir no processo legislativo, com o objetivo de garantir a liberação comercial desses produtos. Assim, no campo da biotecnologia, houve a universalização dos dispositivos jurídicos orientados à proteção da propriedade intelectual, objetivando a garantia dos direitos patentários de 
produtos gerados pela pesquisa. As mudanças no marco legal de regulatório legitimam as ações empresariais e conferem previsibilidade às redes, em suas relações interempresas.

No Brasil, a pesquisa pública sempre foi importante nos programas de melhoramento de cultivares de soja, cuja produção e comercialização ocorriam por meio de sistemas de parcerias com o sistema cooperativo e algumas empresas nacionais privadas. Mas, a partir da aprovação das Leis de Proteção de Cultivares e de Propriedade Industrial, o perfil da produção de sementes de soja foi reestruturado, com a introdução de cultivares próprias de grandes empresas transnacionais como a Monsanto.

Os novos dispositivos legais possibilitaram a criação de uma rede empresarial, estruturada por meio de vários contratos formais, que delimitam as ações de cada organização dentro do sistema e que garantem melhor competitividade para atuar no mercado. As redes de parcerias se fundamentam nas celebrações de contratos na área de pesquisa e desenvolvimento de sementes, assim como de licenciamento. O licenciamento é utilizado tanto para o pagamento dos royalties da soja transgênica como para a utilização de uma determinada cultivar. As redes de produtores de soja transgênica também servem para legitimar e isolar as instituições que porventura se oponham a esta inovação agrícola. Se a Monsanto usasse somente as suas cultivares, não teria a capiliaridade para atingir um número maior de agricultores. Portanto a formação de parcerias entre diversas empresas públicas e privadas facilitam tanto a difusão da soja transgênica quanto a legitimação perante outros agricultores e à sociedade.

A assinatura do convênio de cooperação, firmado entre a Embrapa e a Monsanto, abriu a possibilidade para a Monsanto utilizar a densa rede de empresas e de produtores de sementes parceiros construída pela Embrapa, como foi o caso do CTPA, em Goiás. Nessa rede, a Monsanto domina a tecnologia da soja transgênica, mas não tem cultivares suficientes que possam ser disseminadas com maior abrangência. A Embrapa não dispõe da propriedade intelectual da soja transgênica, mas conta com um grande número de cultivares de soja adaptadas às mais diversas regiões do Brasil. Através do contrato, foi permitida a entrada de novas empresas à rede, na medida em que Embrapa tinha outros parceiros - CTPA - que além de participar dos processos de pesquisa e experimentação, são corresponsáveis pela administração do sistema. Os produtores de sementes vinculados ao CTPA entram com o investimento, assim como pagam royalties para a Monsanto e Embrapa.

Com a organização dessa rede, verificou-se a adoção inicial da soja transgênica em Goiás de uma forma surpreendente, cerca de $30 \%$ de toda produção de semente. Na safra 2010-2011, segundo um gerente da CTPA, a soja transgênica já era responsável por $70 \%$ de toda área semeada. Portanto a tecnologia transgênica está se expandindo consideravelmente no mercado de semente, sem uma discussão profunda do real benefício social e econômico dessa inovação. A Embrapa cumpre um importante papel na rede empresarial na difusão da soja transgênica em Goiás. Daí o questionamento sobre o papel de uma empresa pública que se coloca a serviço de empresas que têm como objetivo principal o lucro, e não a construção de uma agricultura mais sustentável, orientada para as questões de bem-estar da população como um todo. Outra questão importante a se refletir é o monopólio da tecnologia transgênica, que deixa poucas margens de escolhas para os agricultores de Goiás, pois a ampla e rápida difusão de soja transgênica reduz as margens de escolhas para os agricultores, sem o necessário aprofundamento do debate sobre as implicações econômicas, políticas, sociais e ambientais decorrente da tecnologia dos organismos geneticamente modificados.

\section{Referências}

BRASIL. Lei n. 11.105, de 24 de março de 2005. Regulamenta os incisos II, IV e V do $\S 1^{\circ}$ do art. 225 da Constituição Federal, estabelece normas de segurança e mecanismos de fiscalização de atividades que envolvam organismos geneticamente modificados - OGM e seus derivados, cria o Conselho Nacional de Biossegurança - CNBS, reestrutura a Comissão Técnica Nacional de Biossegurança - CTNBio, dispõe sobre a Política Nacional de Biossegurança - PNB, revoga a Lei no ${ }^{\circ}$.974, de 5 de janeiro de 1995, e a Medida Provisória no 2.191-9, de

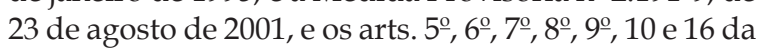
Lei no 10.814, de 15 de dezembro de 2003, e dá outras providências. Disponível em: <http:/ / www.planalto. gov.br/ccivil_03/_Ato2004-2006/2005/lei/L11105. htm>. Acesso em: 20 out. 2008. 
. Lei n. 9456, de 25 de abril de 1997. Institui a Lei de Proteção de Cultivares e dá outras providências. Disponível em: <http:/ / www.planalto.gov.br/ccivil/ leis/L9456.htm>. Acesso em: 20 out. 2008.

Lei n. 9.279, de 14 de maio de 1996. Regula os direitos e obrigações relativos à propriedade industrial. Disponível em: <http://www.planalto.gov.br/ ccivil_03/Leis/L9279.htm >. Acesso em: 20 out. 2008.

BUAINAIN, A.; CARVALHO, S. Propriedade Intelectual em um Mundo Globalizado. Parcerias Estratégicas, Brasília, n. 9, p. 145-153, out. 2000.

CARVALHO, S. M. Política de propriedade intelectual no Brasil: intervenções nos campos de saúde e de sementes. Brasília: IPEA, 2005. n. 1140.

CASTELLS, M. Sociedade em rede: a era da informação: economia, sociedade e cultura. São Paulo: Paz e Terra, 1999. Vol. 1.

ELIAS, D. Globalização e agricultura. São Paulo: Edusp, 2003.

EMBRAPA. Contratos da Embrapa com a Monsanto. Disponível em: <http/www.embrapa.br>. Acesso em: 30 jun. 2006.

. Política de negócios tecnológicos. Brasília: Embrapa/SPI, 1998.

GUERRANTE, R. Transgênicos: uma visão estratégica. Rio de Janeiro: Interciência, 2003.

HARVEY, D. A condição pós-moderna: uma pesquisa sobre as origens da mudança cultural. Petropólis: Loyola, 2001.

MAZZALI, L. O processo de reorganização agroindustrial: do complexo à organização em "rede". São Paulo: Ed. da Unesp, 2000.

MAZZALI, L.; COSTA, V. As formas de organização em rede: configuração e instrumento de análise da dinâmica industrial recente. Revista de Economia Política, São Paulo, v. 17, n. 4, p 121-139, out./ dez. 1997.

MINISTÉRIO DA AGRICULTURA, PECUÁRIA E ABASTECIMENTO (MAPA). Dados das cultivares protegidas: SNPC, 2006. Disponível em: <http://www. agricultura.gov.br>. Acesso em: 15 jun. 2006.
MIRANDA, L. Novas concepções de parcerias na Embrapa. 2005. Disponível em: <http:/ /www.abrasem.com.br/ materia_tecnica/2005/0004_nova_concepcao.htm>. Acesso em: 25 out. 2006.

MONSANTO. Notícias, [S.1., s.d.] Disponível em: <http://www.monsanto.com.br>. Acesso em: 26 jun. 2005.

PESSANHA, L.; WILKINSON, J. Transgênicos provocam novo quadro regulatório e novas formas de coordenação do sistema agroalimentar. Cadernos de Ciência e Tecnologia, v. 20, n. 2, p. 263-303, 2003.

Transgênicos, recursos genéticos e segurança alimentar: o que está em jogo nos debates? Campinas: Armazém do Ipê (Autores Associados), 2005.

RETEC. Encontro de propriedade intelectual e comercialização de tecnologia. Rio de Janeiro: Rede de tecnologia do Rio de Janeiro/INPI; Brasília: ABIPTI, 2002.

RUBIO, B. Explotados e excluidos: los campesinos latinoamericanos en la fase agroexportadora neoliberal. México: Plaza y Valdés, 2001.

SANTINI, G; PAULILLO, L. F. Mudanças tecnológicas e institucionais na indústria de sementes no Brasil: uma análise aplicada aos mercados de milho híbrido e soja. Agricultura em São Paulo, v. 50, n. 1, p. 25-42, 2003.

SHIVA, V. Biopirataria: a pilhagem da natureza e do conhecimento. Petrópolis: Vozes, 2001.

SILVA, J. G. Tecnologia e agricultura familiar. Porto Alegre: Ed. Universidade/UFRGS, 1999.

VEIGA, J. E. O "fordismo" na acepção regulacionista. Revista de Economia Política, São Paulo, v. 17, n. 3, p. 63-70, 1997.

WILKINSON, J.; CASTELLI, P. A transnacionalização da indústria de sementes no Brasil: biotecnologias, patentes e biodiversidade. Rio de Janeiro: ActionAid Brasil, 2000.

ZYLBERSZTAJN, D. Papel dos contratos na coordenação agro-industiral: um olhar além do mercado. Revista de Economia e Sociologia Rural, Rio de Janeiro, v. 43, n. 3, p. 385-420, jul./set. 2005.

ZYLBERSZTAJN, D.; LAZZARINI, S.; MACHADO FILHO, C. Avaliação dos impactos de variedade transgênicas no sistema agroindustrial. Revista de Administração, São Paulo, v. 34, p. 21-31, jul./set. 1999. 